\title{
Women in Estonian jokes ${ }^{1}$
}

\author{
Liisi Laineste
}

\begin{abstract}
The article focuses on jokes about women in Estonian jokelore from 1960 s to 2010 . Jokes where a woman is either mentioned or present will be analysed. Neutral words for describing the female character were used as search words in compiling the dataset; this gives an idea how the character appears in jokes about everyday life. A set of 2000 jokes about women and marriage were extracted from a bigger database of Estonian contemporary jokes, and 1869 of these were suitable for the present analysis. We have taken into account that joke-telling has primarily been a male practice. This has affected gender stereotypes in the jokes making them more aggressive and misogynistic. Another aspect that has had a say in shaping family jokes is the overall political undertone of the Soviet jokes which have carried on to present-day jokelore.

The study describes the context (setup of the joke), the characteristics of the targets (e.g. role), and the change thereof through the periods of socialism and post-socialism. The tendencies in placing the female character in either familiar surroundings (home) or in the public sphere throw light on common beliefs about the suitable context for a woman as well as persons accompanying her in those locations. As a result, we will be able to describe the portrayal of gender roles in their societal context.
\end{abstract}

Keywords: gender jokes, family jokes, stereotypes, gender roles, post-socialist jokelore

\section{Introduction}

Gender has long been the subject for jokes, and according to scholars it is one of the most recurring categories, along with ethnic and political humour (Winick 1976; Davies 1998). As Rappoport aptly notes (2005: 102), there are at least three generalisations about sexual humour that are acknowledged by all authorities on this topic: (1) it is virtually found in all societies around the world;

\footnotetext{
1 The research was supported by ETF8149.
} 
(2) these are jokes told by men, who in general are more frequent joke-tellers, so it is only logical that gender jokes should be on the subject of stereotypes about women; and (3) women still tend to laugh more at jokes told by men, even if they are about gender stereotypes, which makes the jokes perpetuate more easily. Although these points do not account for much of homosexual jokelore, that about/by homosexual women in particular, they do illustrate the background for this study in which the latter forms a vanishingly small share of the material.

Researchers do not share a general agreement regarding the relationship between folklore (in this case, jokes) and the surrounding social reality. Some say jokes reflect the reality (e.g. Shifman \& Lemish 2010), while others claim that the relationship is more complicated than that and that it stretches and distorts the reality rather than mirrors it (Oring 2003: 59). This implies from a slightly different perspective that researches cannot draw conclusions about the intentions or attitudes of people simply by considering their jokes (e.g. Davies 2011; Oring 2003). Humour as a form of communication is far too ambiguous. There is a general consensus that humour is playful (or non bona-fide mode, as Raskin (1985) puts it), but that places the weight of responsibility solely on the receiver when we are making decisions about the meaning of a humorous utterance: intentions can be manifold, but in the end it is the listener who will decide if the utterance was aggressive or funny. If the remark is interpreted as aggressive, the sender can accuse the receiver of lacking a sense of humour, and use this as a disclaimer about his or her authentic motivation. This tendency has been described on a number of racist web sites in the UK and USA (Oring 2003: 41-57; Billig 2001). Whether the motives of the joke-tellers (or, for that matter, of those who share jokes on the Internet) are obvious and can be deduced from their utterances or not remains a topic for discussion. Many researchers (above all Davies 1990, 1998, and most recently 2011; Oring 2003) are of the opinion that jokes as an inherently ambiguous form of communication cannot transparently reflect the attitudes or motives of their tellers. In order to express genuine anger or dissatisfaction, more efficient communicative tools are available and using humour would hopelessly blur the situation. Even when a particular stereotype raised by a joke can be pinned down, the position of the teller may remain completely unclear and dependent on the situation (e.g. feminists telling sexist jokes between each other about women versus men sharing sexist jokes in an all-male environment). At the same time, even when objecting to the stereotypes in the joke and just quoting the dumb "silent majority", one helps to entrench the ideas (Billig 2005).

Although the study of stereotypes would generally include a clear statement in these questions, this article concentrates on describing Estonian jokes about women rather than performing cultural analysis on the emergence and maintenance of the stereotypes embedded in the jokes. However, one can agree 
that jokes differ from one cultural context to another and thus represent the preferences of a certain group of people in how to portray "others", in our context, women. In the analysis, we do not differentiate between different subgroups of women; neither do we target different groups of joke-tellers (e.g. homosexual women telling jokes about women). As is evident from research (see references in the next section), the recently multiplying non-misogynistic, empowering jokes about/for women form still a marginal section of the category of jokes that feature a woman character.

\section{Woman as the "other"}

Similarly to ethnic humour, gender humour is also based on the juxtaposition of "us" and "them", and as joke-tellers have traditionally been male, it is the female character who fills the inferior role of the "other". This male dominated perspective in gender humour has been frequently analysed by different authors (Franzini 1996; Crawford 2003; Bing 2007; Shifman \& Lemish 2010), most often from the feminist point of view. In more recent studies, there are actual areas of joking where the traditionally misogynistic viewpoint is twisted into a feminist joke (Bing 2007), and Nadine Thielemann (2011: 169) has described new Russian jokes where the punch line is delivered by a female. Linguistic as well as sociological studies have recently added insight into the stereotypes that are constantly displayed in our society (above all, in public discourse like the media). The ideas about the gendered "other" are visible in a number of channels that public discourse uses: television programmes (humorous as well as serious), public talks by opinion leaders, advertising campaigns, etc. The results of these studies have shown that gender representations are grounded in deep-rooted constructions of femininity and masculinity which are based on binary as well as hierarchical oppositions (Nussbaum 2010; Van Zoonen 1994). This implies that women are regarded not only as different (as does feminist and post-feminist humour, described by Shifman \& Lemish 2010), but also inferior to men. A woman has long been regarded as a sexual being who can only be evaluated on the basis of her appearance (Lemish 2008). Blonde jokes, for example, stand out as an excellent example of regarding women as sex objects, beings void of any thought and even deprived of having a personality. The stereotypes used for women in the humorous texts and pictures by men have contributed to the image of the negative, non-humorous woman. Most gender jokes can be cast as sexist, whereas there are also those that make fun of the male stereotypes about females by positioning oneself higher than the narrow-minded "typical joke-teller" (see also Bing 2007). In this light, it is quite comprehensible that jokes linger on these stereotypes with persistence and pleasure. 
Until recently, studies in the sociology of humour have found that men tell more jokes and are also the initiators of humorous interactions. Researchers stress the fact that masculinity and joke-telling are expected to correlate, whereas women are more often the ones laughing at the jokes men tell them (Kuipers 2006). At the same time, according to Holmes \& Stubbe (2003: 578) women increasingly initiate extended humour sequences in workplace conversations and negotiations in order to create a positive and versatile atmosphere. The essence of this contradiction could be in the genre: as Kuipers maintains (2006: 44-47), Dutch women who participated in her study preferred other humorous genres like personal narratives and were allegedly not skilful joketellers, whereas men believed jokes to be the best form that humour can take. Men who were interviewed about their styles and preferences of humour (ibid.) argued that women do not remember and are not able to tell jokes, as they "start with the punch line, laugh before the end, are too shy, too cautious or too proper". Men, on the other hand, regard themselves as relatively good joketellers, and seem to win esteem and admiration from telling a good joke. All in all, women do not seem to value jokes or the ability to tell them, whereas men do, and it is the men telling the jokes who enjoy the more or less veiled animosity and misogyny in jokes. This does not, however, pose an impediment for women to liking sexist jokes: groups with lower social status regularly tend to enjoy (and thus reinforce) jokes at their own group's expense (Kuipers 2006: 186-187). And if not, recognition among other heterosexual males in a pub or other joke-telling context is enough for the jokes and stereotypes to perpetuate. These dispositions may well vary across cultures and times, but current research about Western joke-telling standards favour strictly the male joketelling ability over the woman's.

Among gender jokes, different sub-groups emerge. These can be divided upon the identity of the female character. For example, gender jokes may be about blondes, mothers-in-law, JAPs ("Jewish American princesses"), and feminists, just to name a few. Rappoport (2005: 112) notes that the classic targets of mothers-in-law, dumb blondes, Jewish mothers and JAPs (last two of which are typical Northern American joke categories) have formed a solid base for all male comedians' standard equipment, rather than jokes about women in general. Jokes about these groups are quite varied and easily identifiable, carrying a specific stereotype: dumb blondes as hypersexual bimbos, JAPs as asexual shopaholics, mothers-in-law as nagging tyrants, etc. These are also the subgroups that appear most often in academic discussions, leaving no or little attention to the image of the more neutral woman (the classification "neutral" is of course tentative here, because the essence of jokes is anything but neutral). Thus it is only logical that the present study concentrates on the quite neglected and most general subtype, the wide category of a woman / wife 
/ young woman (but not the blonde or some other more clearly delineated and specifically stereotyped sub-groups) as this allows an insight into the image of the woman without getting caught in the clearly stereotyped subgroups. As Shifman \& Maapil Varsano (2007) point out, sexist jokes that depreciate women through general, indirect stereotypes are often regarded as "clean" jokes suitable for all audiences without any censorship: cleanliness is only a socially accepted screen that hides the inherent contradictions of these texts. These are the most widespread ones on the Internet, helping to disseminate the stereotypes even further. This is exactly what jokes about women are: they do not convey any clearly inappropriate or aggressive views, but at the same time they do embed sexist stereotypes (sometimes of both sexes) that familiarise the listeners to those stereotypes in a permissive context.

Marriage is a common target for so-called clean jokes. The reasons for this run deep in the tradition itself. Marriage has always been very important to the majority of societies. At the same time, it comes with a lot of frustrations. Being married was a pervasive ideal of the immediate past (Stone 1992, cited by Strean 1993: 87): many cultures idealised the institution, and pressure was placed on young people to find a mate; it could even be a sin to remain unmarried. Nevertheless, the concerns that have accompanied the institution still remain. This gives rise to jokes about fussy wives who spend too much money, cannot cook, or exceed their power limits at home with their husbands:

Son asks: "Daddy, who is the master of our house, you or mommy?"

"Me, of course, why?"

"But why do you always sleep on the doormat then?"

"Well, my son, the master can sleep wherever he wants."

(Delfi, 26.06.2000)

But in most cases it is the man who has to deal with the seemingly endless tragedy involved in being married to an inferior human being who can just be called a "malady":

Doctor in a sanatorium addresses an old client: "You are here again with your old malady?"

"No, this time my wife decided to stay at home."

(Eesti Päevaleht, 11.05.1998)

Other jokes from this most general subcategory of gender jokes also deal with the same institution, either directly or less so. Jokes about young women revolve around their ability to find a partner (a joke was reported of a girl who filled in a form and marked "hopeful" in the slot asking for her "marital status"). Jokes about extramarital affairs were numerous in the sample we analysed for this study. As is visible from our results, the husband is by far the most popular 
interaction partner for the female character (see analysis below). While blonde jokes display the image of the promiscuous woman / girl (who may even be regarded as empowered in her choice to be openly sexual, were it not for her total inability to reflect on her actions or control them), the choice of stereotypes for the jokes about women in general is more varied, and sex is rarely considered to be an issue.

Humour inevitably comes from a perception of social contradictions. The role of the woman, but also the general institution of marriage as such, is obviously a representative of such a contradiction. In our study, we have analysed joke texts, without considering immediate social context or performance aspect, but in order to get to the ambiguities in social environment that have given rise to these jokes, we have always kept the wider societal context in mind. This is important in understanding why the jokes are what they are, and what has affected their change.

\section{Research material: Database of Estonian jokes}

A joke is generally perceived as created by the people and not belonging to any one author (also stressed as an important feature in sociological research in Davies 2011; Kuipers 2006: 6), which makes it a long-standing folklore genre. This in turn strengthens the argument that when a joke is widespread, i.e. people like to tell and listen to it, there must be something in the joke that reinforces this behaviour. In a word, the joke is thus considered to be representative of some facet of life. The genre is quite volatile in face-to-face communication, and collecting an ample body of material for research can be a painstaking enterprise. The database of Estonian jokes (1950-present day) consists of various sources: collections from folklore archives sent by people who have told / heard the jokes, Internet joke collections, and active portals where Internet users can send jokes, comment on their own or others' jokes, or evaluate them, etc. The database forms a great starting point for analysing any category of jokes, and although it lacks oral material from after the 1990s, the blend of orality and literacy on the Internet cancels out this drawback. We can even say that most jokes now circulate on the Internet (via emails, social media, portals, etc.), and thus represent the real proportions of targets, subjects and genres preferred by the people quite accurately. Besides, jokes on the Internet come with a contextual set of information that can be of great importance in processing the data: type of the website (dynamic or passive), date, sender (frequent or accidental), and also its placement in a category and other additional knowledge about the joke is sometimes openly accessible on these joke-sharing sites (see also Oring 2003: 139-140). 
Jokes have been called the fruit flies of humour research for obvious reasons: they are abundant, easy to approach, and have a long history in humour research just as these insects have in genetics. In addition to this, there are other reasons for selecting jokes as a primary research target (see Kuipers 2008). The genre is popular, and exceedingly so on the Internet. Jokes also represent a standardised form of communication, which makes them extremely similar in both speech and writing (even if some aspects go missing in the latter). And last but not least, jokes are global, but culturally specific social phenomena, representative of their surroundings, which makes researching them informative about the people telling these jokes. This in turn gives the endeavour of researching jokes about women a clear cause and reason: describing the jokes that are told about women allows us to access the stereotypical roles and situations that are inherent in jokes, which in turn carry significant cultural and sociological insight into the representation and its backgrounds.

\section{Methodology}

By choosing the image of a linguistically neutral "woman", "wife", "mother", and "young woman" to be at the core of our sample, we aimed at ending up with material that would represent the generalised image of a woman, not its strongly stereotyped sub-categorisations, so far as neutrality is possible while dealing with jokes. We omitted words like "spinster", "prostitute", or "motherin-law", all of which carry a strong set of specific stereotypes. Likewise, we did not include jokes about blondes because the stupidity script that is embedded in the jokes does not convey information about women as such, but rather stands for more general societal phenomena as aptly described by Dundes (1987), Oring (2003), Davies (2011) and elsewhere. Another non-inclusive category is jokes about female popular figures, because these jokes are often recycled from blonde jokes or jokes about women in general; besides, they do not represent the category of a neutral woman that was our main subject. We did not filter out the texts that included the stereotyped characters (there were jokes, for example, where a woman would be talking to her mother-in-law), but in analysing the jokes we concentrated on the position of the "neutral" woman rather than the other female character, e.g. in this case, the mother-in-law.

We examined a set of joke texts that featured at least one female character. The sample was compiled through a customised search for texts containing words like "woman", "wife", "mother" and "young woman", using the database of Estonian contemporary jokes which consists of ca 50,000 joke texts. We did not differentiate between jokes about men or women; neither did we make a distinction between jokes where a woman is actually present and those where 
the female character is just a topic to talk about. In any case, the way the jokes reflect women is informative of her status and role in the society. We excluded repetitions that did not show any variation, leaving only the first appearance of this joke in the material. Variations of one type were kept in the dataset and categorised according to the instructions.

The final sample consisted of 1,869 jokes, which remained from the initial 2000 when a secondary sampling was performed to omit duplicates and incomplete jokes. The material was then categorised according to four larger categories: (1) location, (2) other characters present or mentioned in the joke, (3) sexual content, and (4) the role of the woman in the joke. The categorisation principles were vested in the research question: to describe how women are mentioned in the context of jokes, and choose aspects thereof that allow least contradictive categorisation (for this reason, e.g. omitting category "stereotypes"). Each of these categories was divided into further subcategories that were examined individually and in interaction with other subcategories. The location category included different places in one's home and outside. Characters were divided into family members and non-family members. We marked the sexual content by tagging the joke as either containing a sexual reference or not. The position of the woman mentioned/acting in the joke could be either the target or the protagonist, or in a neutral / irrelevant position. In a number of cases, the first two categories were not applicable due to the brevity of the joke (e.g. question and answer jokes), but the sexual content or lack of it as well as the position of the woman, were marked in most cases. Categorisation can be found in Appendix 1.

The final sample was analysed by using the qualitative text analysis programme QDA Miner. The results of simple descriptive statistics received additional support from more detailed statistical analysis methods provided by the programme, above all calculations of code co-occurrence and sequences.

\section{Results and discussion}

First, we present a general overview of the results. Descriptive statistics of the categories will illustrate some general trends in the material. We then proceed with some subcategories that provided unexpected or interesting results, and describe their interactions with other categories. A section in the discussion will be dedicated to more controversial issues, e.g. the role and voice of the woman in Estonian jokes. 


\section{Location}

Location was identifiable in 750 cases. In the rest of the jokes, the place was not mentioned; neither could it be deduced from the nature of the situation.

In 411 cases, which are more than half of the category, the woman was acting within her own home as opposed to outside the home. The category was in turn divided into four subcategories: living room (262 cases), bedroom, kitchen and bathroom. The latter was represented in only a few cases. A factor that amplified this distribution was the fact that when the location was implicitly, but clearly "home", but the specific room was not mentioned, the categorisation instructions required using "living room" as the most general and neutral space at home. Nevertheless, the distribution is quite plausible and suggests that women mostly act in the living room or the bedroom. Slightly surprising was the relative lack of instances where "kitchen" is the location of the joke, and this is supported by the portrayal of women as inefficient or even destructive in the kitchen. For example:

A young wife sits in the kitchen and sighs to her husband: "Today was the first day that I cooked something for dinner, and now the cat has eaten it!" "Darling, don't worry. We'll buy a new cat."

(Delfi, 21.04.2000)

The second subcategory of location was outside the home, which was in turn divided into anonymous and personal public space.

Being in a personal public space (e.g. hospital, theatre, shop, etc.) meant that the woman in the joke was personally involved in communicating with people working or acting there and that the location was the target of her journey. The category was represented by 209 cases. The most popular locations in the public space personal subcategory were at the doctor's or in the hospital (50 cases), followed by theatre/cinema (39 cases), police station or court (28 cases), workplace (23), school (19), restaurant (14), church (6).

The impersonal space outside one's home was represented by 130 cases, and the most usual places were city space (e.g. city streets; 70 cases), public transport (33) and nature space (outside the city, beach, etc.; 27).

This distribution conveys a general idea of the typical woman acting most often at her home, but when outside, running some errands that involve personal communications with shopkeepers, public officers, doctors, and other customer service assistants. At the same time, the frequency of cases that imply impersonal space is not much lower. More discussion will follow below in the section dealing with relations between location and interaction partners. 


\section{Other characters present or mentioned in the joke}

This was a more easily assignable category than that of location, resulting in a categorisation in 1,657 cases. In the rest of the cases, the woman was either acting alone or it was not possible to identify her partner. This general category was divided broadly into two: communicating with members of family $(1,139$ cases) or with people outside the family circle (518 cases). As it is clearly evident, women were more involved in talking to / interacting with relatives than with non-relatives, which confirms the trend set down by the preferable location for a woman - at home. Further on, we divided the interaction partners into subcategories, of which the most popular ones were husband (802 cases), children/grandchildren (264), mother/father (61, relatives through marriage (8), pets (4). In the second subcategory, the possible non-related partners were distributed in the following pattern: stranger (140 cases), public officer / shop assistant / worker (114), male friend (101), lover (89), female friend (53), boss (21). This shows that the husband is by far the most frequent partner for a woman; children also appear quite often, whereas all other characters turn up in jokes much more rarely. It is interesting that the lover is not a very frequent character, falling behind the male friend (present in jokes with non-sexual content, hence the difference - as you see below, the number of jokes with sexual content was small, most probably because of the nature of our sample, thus reinforcing the idea of at least surface level neutrality of these jokes). The relatively frequent presence of the "stranger" character is surprising, and the jokes where the woman interacts with the stranger tend to be sexual ones, where the woman is not just the victim but sometimes the knowing, initiating and maybe even the winning character:

Cannibals have caught a white woman who was lost in the jungle. They want to eat her up at once, but the head of the tribe carries the woman to his den and doesn't come out for three consecutive days. Hungry cannibals get impatient and gather around his hut to protest. Finally the chief comes out and turns to his people: "Did I weep when our enemies killed and ate up my mother and father?" - "No, chief, you did not!". - "Did I weep when my son fell into the river and was eaten by the crocodile?" - "No, chief, you did not!". - "But now, when I go to take a leak behind my hut, I weep...!" (Jüri Viikberg, 1976) 


\section{Sexual content}

Sexual content was categorised simply into yes or no. Ambiguous statements sometimes revealed sexual content, but more often the situation was rather obvious. Continuing from the previous categorisation where a woman deals with strangers in the public space with confidence and even aggression, the following joke can be an example:

A massive woman steps into an elevator where a little, skinny man is standing.

"Well, little man," the woman asks, "aren't you going to rape me?"

"Oh no, god forbid, no!" answers the startled man.

"Oh yes, you will! Don't think you can get out of it!" says the woman standing arms akimbo.

(Delfi, 18.12.2001)

Sexual content was present in $27 \%$ of jokes, which is a lot less than was expected. This means that the character of the more neutral "woman" in our sample does not appear in jokes that talk about sex so often than the more stereotype-laden subcategory of the blonde, for example. It also supports the idea of family jokes being generally non-sexual, although this does not strip these jokes of negative stereotypes altogether, but rather presents them in a context that makes the inherent stereotypes seem mild and acceptable.

\section{The role of the woman}

This category was the least clearly delineated, and subjective interpretations of a joke text influenced the categorisation. We expected this division to give us ideas about how the woman is positioned against other characters and show whether the seemingly neutral woman in the jokes is really neutral or, instead, an underdog in the masculine framework of joke-telling. We assessed the role of the woman, casting the category into three subdivisions: a woman as the target of the joke or a clear underdog (in 607 cases); a woman as the protagonist in the joke, turning the situation in her favour and making fun of the other characters in the joke (328 cases); and a woman as a neutral side character who actually bears no particular importance in the punch line of the joke (937 cases). This means that about $50 \%$ of the material featured texts that were not about the female character at all; instead, the protagonist - or, the target - was a man (most often, with reference to the data above, the husband). This confirms that men as joke-tellers reflect their own issues rather than focusing on portraying the women and their problems. In the long run, the joke is still more often about the man with his vices and virtues. The subject will be addressed below 
in the section dealing with the role and voice of the woman in the masculine world of jokes.

\section{Co-occurrence analysis: Location and other characters in the joke}

Regardless of the developments in the distribution of roles and professions in our present world, jokes seem to represent a patriarchal and centuries-old view about the place of the woman. Women are associated with the domestic environment, where they act in $56 \%$ of the cases. $44 \%$ of jokes take place outside the home. Other characters in the jokes where home is the background are also "domestic", i.e. family members, usually from the immediate family: husband and children. There were only a small number of cases where the other character was a non-relative, of which the more frequent was a friend or a lover. When the action took place in the bathroom, the woman was most often (37\% of the cases that involved both categorisations) washing her children. In the living room and in the kitchen, the husband was the interaction partner (19.4 and $29.3 \%$ accordingly). Only in the bedroom did the family members get some competition from non-relatives, as besides the husband ( $28.4 \%$ of cases), the lover was also a somewhat frequent guest there $(8.1 \%)$. When we look at the number of different character categorisations, we find the living room to be most inhabited with different groups of people, with both relatives and non-relatives alike. This is quite expected as the living room is the most neutral of domestic spaces and is suitable for entertaining visitors. In addition to husbands and children, female and male friends, strangers, workers, lovers and even the boss (in one case) visited the living room. The most colourful jokes that take place in the domestic environment tend to be the ones involving the woman and her lover (and, as a matter of fact, quite often the husband as the third character):

A woman has brought home her lover, and they are in the bedroom when suddenly and quite unexpectedly the husband comes home. The wife hides her naked lover in the closet. At night when everyone was asleep, the lover starts to leave, sneaking out of the closet. Suddenly the man hears him and asks:

"Who's there?"

"Just a moth."

"And where are you taking my wife's fur coat?"

"I want to finish eating it at home."

(Eesti Päevaleht, 22.05.1998)

As we predicted, the people with whom a woman communicated with outside her home were more often non-relatives when compared to the choice of communication partners at home - although the husband is still the most popu- 
lar communication partner outside the home too (in $9.7 \%$ of the jokes taking place outside the home). Among them, strangers rank the highest (in $8.2 \%$ of the jokes that take place outside the home), being followed by co-workers and bosses. This is especially the case in jokes where a woman walks on the streets or rides in public transport:

It is rush hour. Little Peter sits on his father's lap on a very crowded bus. At the next stop, an old woman, heavily leaning on a walking stick, gets on the bus. Peter jumps right up and says: "Please, take my seat!"

(Eesti Päevaleht, 18.10.1998)

The example is also typical of how the categorisation system worked: although the man and his son Peter are in the centre of this joke, they are categorised as "strangers" because from the viewpoint of the woman in the joke she is not familiar with either of them.

Other popular non-relatives, co-workers and bosses, are present mostly at work. These locations (street, public transport, work, and also doctor's office and shop) are the only places outside the home where the husband is not the primary interaction partner. The same goes for the workplace. In other cases - in the court / police station as well as in a theatre / cinema - the husband is the one that the woman interacts with. A small exception is presented by the church, where the woman usually goes with her children and not the husband.

All in all, regardless of the location (whether it was at home or outside it), the husband remained in the position of the most important partner in jokes, but outside the home he does get some competition from non-relatives.

\section{Co-occurrence analysis: Sexual content and location, other characters in the joke, and roles}

As already mentioned, sexual content was tagged in $27 \%$ of the jokes. This is quite low, considering that joke-telling is a male practice and gender jokes should bring up some sexual connotations. The reason for this is the choice of neutral search words. In this section we are going to discuss the cases where sex was a subject in a joke.

If we examine the interaction between sexual content and location, there is a tendency that the subject matter of the joke contains sexual hints more often when the action is taking place outside the home. The combination of cases where "outside home" was tagged alongside with "yes" to sexual content was quite high: $45.8 \%$ of jokes taking place in the public space talked about sex. At the same time, and contrasting to this, $72.1 \%$ of jokes taking place at home did not mention sex. Instead, a number of other, cleaner and less provoking themes 
were common like doing daily chores, dealing with children, talking about the day or nagging each other. A few examples:

A young woman is bathing her baby. The neighbour's little daughter, holding a doll with one leg and no hands, is watching her. Suddenly she asks: "How long have you had it?"

"Three months," answers the mother.

"Wow, then it is still looking pretty good!"

(Sõnumileht Online, 05.08.1998)

Sexual content was present in jokes that took place in the public space both indoors and outdoors:

A girl is late for a date. "Try to understand, honey, a strange guy followed me all the way!" she explains.

"So?" asks her date.

"You just can't imagine how slow he was!"

(Kuldar Metsa naljakogu, 1998)

A woman rushes into a police station and screams: "I have just been raped by eight men!"

"Don't worry, we'll catch them all."

"No need to catch them all, just arrest the second and the fourth!"

(Kuldar Metsa naljakogu, 1998)

The woman was quite often the active protagonist, or at least the one dictating the pace and content of the sexual encounter (in $40.7 \%$ of the jokes where sex was a subject, the woman was an active subject and not the passive target or side-character). In this case, the sexual inability of a man was often the topic of the joke. A lot of jokes talk about the marital relationship and its shortcomings:

"Mommy, what's an orgasm?"

"I don't know, go ask your daddy!"

(Meie naljaraamat, 02.12.1997)

The main characters in sexually laden jokes besides the woman are her husband, a stranger, or (as seen from the previous example) the children. Of all the sexual jokes, 6.6\% featured a stranger acting together with the woman. According to the above results, sexual content was present outside the house, but even so, the husband was interacting with his wife in $16.4 \%$ of the sexual jokes (compared to $20.9 \%$ of all the cases where sex was not an issue) - more often outside the house:

A man went to a spa. He chased women, fought with other men over women and generally behaved badly. He ended up with a glass eye. After three 
weeks it was time to go home. All the way in the train he was wondering what he would say to his wife if she asks about the glass eye. The train arrived and he saw his wife coming towards him along the platform. He didn't even have a chance to greet his wife when she cried out: "Don't look at me so reproachfully! I promise, I'll tell you everything!"

(Delfi, 07.11.2001)

The interaction partners in non-sexual jokes are the husband, as mentioned, and besides him, her female friend and a shop assistant/ doctor / public servant. The following example bears a distinct timestamp, referring to the fact that many Jews were looking for ways to emigrate from Soviet Russia:

A woman in the maternity ward was not happy that the doctor was much more attentive to a Jewish woman than to her. The doctor told her off, saying: "You must understand: all Jewish children are meant for export!" (Ivar Kallion)

\section{Role and voice of a woman}

The woman in our material is above all a side character (see results above). The second role for a woman (in the order of frequency) is that of the target, and the woman acts as an active protagonist only thirdly. She is also a side character in jokes that would assume her greater activity, e.g. in jokes about the woman and her lover. Sometimes in adultery jokes the woman is not even actively on the stage:

"Hi, Robert, may I talk to your wife?"

"Sorry, she's in bed."

"Is she ill?"

"No, she has visitors."

(Sõnumileht Online, 26.08.1997)

In most jokes about adultery, it seems the woman is not targeted for her infidelity, and it is rather the weak and cuckolded man who is mocked here.

It is worthwhile to see how jokes deal with the woman protagonist and her relationships / interactions with men. The relevance of this aspect rests in several justifications: (1) As jokes come from a masculine world, it is uncommon to have a female main character in the joke, but it still does happen and much more often than one could predict; (2) Describing the female protagonists may not help us get a closer view of the stereotypical strengths of a woman, but it does add considerably to our understanding of the opportunities the woman has for asserting herself in a joke (= in a male-dominated world); and (3) The voice of a woman in such jokes may actually be the male representation of 
her voice, which in turn allows a researcher to make statements about hidden stereotypes embedded in jokes. The last statement is the focal point of this section in our discussion.

In describing our material, we should look separately at jokes where the woman protagonist acts on her own or is accompanied by a female friend, and those (a much more numerous category) where the woman is confronted by the man - and wins the argument.

In jokes with only women interacting with each other, the conversation still revolves around men most of the time. Women complaining about the infidelity or stupidity of their husbands prevail. In the few cases when they are not talking about their men, it may also be the other women whom they target in the punch line:

Two women from neighbouring flats are hanging their laundry out to dry.

One sees the other staring at her laundry and asks:

"Why are you staring at my laundry like that, do you do yours any differently?"

"Yes, I wash it before putting it up to dry."

(Delfi, 31.03.2004)

When a woman is laughing at the man, the target character is usually her husband and not just a random man, a stranger. Even if she is talking with her child, the punch line is on the man rather than the child:

A boy comes to his mother:

"Let me take your letter to the post-office!"

"It is raining so hard I wouldn't ever send a dog out on a night like this.

Let you father take it."

(Kuldar Metsa naljakogu, 1996)

We are dealing here with the female voice in what is basically a male world. The jokes about women protagonists are about the strong, self-conscious and confident woman who stands up for all her human rights. At least this is what they seem to be at first sight, because as we take a closer look, the range of rights is not that varied, stressing most her right to be sexually satisfied:

"Let's go to sleep or what ..." mutters the husband.

"First "or what" and afterwards "to sleep"," answers the wife.

(Kuldar Metsa naljakogu, 1997)

All the jokes in our dataset and the few examples quoted here reinforce the female stereotypes that are common from the other joke categories based on role distribution: it is the same home-based, husband-nagging wife that we encounter in the jokes that target the woman as well as those that leave them as mere side characters. We must not search far to find an explanation for that. 
As we are looking at the genre of jokes which have traditionally been a male pastime, these assertive utterances may not be what an originally female voice would say on these occasions. Instead, it is the male stereotype of a female voice which is represented in such jokes.

Even more than being about the strong and self-confident woman, these jokes are about the male fear of being laughed at by the woman. The female has traditionally been the subordinate half of mankind and her laughter symbolises the rebellion against such an order. Besides, ridiculing is one of the weapons that hurt most unexpectedly. Men are used to direct eye-to-eye confrontation, but a sly yet strong blow into a gentle spot can destroy their self-confidence. Women protagonists who are to voice their superiority do it through comical means - the punch line, which they utter, is above all on the man. The man is ridiculed, but is it really the woman who is laughing; maybe it is the joke arising from the male joke-teller's fear of being laughed at, and the joke is essentially about the other men laughing at one incompetent, impotent and subordinate specimen they would not like to resemble in any case.

\section{Conclusion}

Humour dealing with relationships between men and women is universal. Above all, men are the joke-tellers and thus also dictate the content of gender jokes. The present research analysed a sample of Estonian jokes about women in order to describe the general reflection of a "neutral" woman in jokes.

The most obvious result is that, whatever the joke is about, the woman in the joke acts most likely at home and communicates with her husband. All other locations and characters fall far behind these two categorisations. This supports the understanding of jokes as texts that carry old-fashioned and entrenched stereotypes, or, when looking at the results in the light of the last section discussing roles and the position of women, the fear of the joke-tellers (i.e. men) of letting go of these stereotypes. The results show as predicted that the woman is mostly accompanied with her husband at home as well as in most places outside the home, the doctor's office and the shop being exceptions to this rule. A different case is presented by public transport, where the woman tends to interact with strangers. The rarely occurring church is a place where the woman is seen with her children. At the workplace, she obviously interacts with her (female) co-workers or her boss.

A woman rarely interacts with people other than relatives in her home, which was to be expected. A lover and a friend were the only non-relatives more visible in these locations. The kitchen and the living room share popularity in being the place to be with the husband and children, but the living room offers a considerably wider spectrum of possible interaction partners than the kitchen. 
Of all the jokes where sex is not talked about, the other character in the joke is most often a female friend, the boss, a customer service assistant, and even the husband. Of all the jokes where sex is a topic, the other character (or one of the others) could be the husband, but also a stranger or the lover, or otherwise the children.

Generalising the results of women's roles in jokes, we can say that the female character is the target or the subject of a joke more often when interacting with her close relatives, whereas with non-relatives her role was that of a side character. A woman can be a protagonist in the jokes where she is interacting with her children or her husband. These are jokes where the female character is actively involved in the conversation, turning it to her own good, and quite often making fun of the other characters in the joke. The hidden stereotypes that are veiled by the woman's voice (faked by the man behind the set-up) refer back to the male-dominated world of jokes, and further reinforce the widely shared and deeply entrenched beliefs about women.

\section{References}

Billig, Michael 2001. Humour and hatred: The racist jokes of the Klu Klux Klan. Discourse and Society, Vol. 12, pp. 267-289.

Billig, Michael 2005. Comic racism and violence. In: S. Lockyer \& M. Pickering (eds.) Beyond a joke. The limits of humour. New York: Palgrave MacMillan, pp. 25-44.

Bing, Janet 2007. Liberated jokes: Sexual humor in all-female groups. Humor, Vol. 20, No. 4, pp. 337-366.

Crawford, Mary 2003. Gender and humor in social context. Journal of Pragmatics, Vol. 35, No. 9, pp. 1413-1430.

Davies, Christie 1990. Ethnic jokes around the world. Bloomington and Indianapolis: Indiana University Press.

Davies, Christie 1998. Jokes and their relations to the society. Berlin, New York: Walter de Gruyter.

Davies, Christie 2011. Jokes and targets. Bloomington: Indiana University Press.

Dundes, Alan 1987. Cracking jokes. Studies of sick humour cycles and stereotypes. Berkeley: Ten Speed Press.

Franzini, Louis R. 1996. Feminism and women's sense of humor. Sex Roles, Vol. 11, No. 12, pp. 811-819.

Holmes, Janet \& Maria Stubbe 2003. Power and politeness in the workplace. A sociolinguistic analysis of talk at work. London: Longman.

Kuipers, Giselinde 2006. Good humor, bad taste. A sociology of the joke. Berlin/New York: Mouton de Gruyter.

Kuipers, Giselinde 2008. The sociology of humor. In: V. Raskin (ed.) The Primer of Humor Research. Berlin/New York: Mouton de Gruyter, pp. 365-402. 
Lemish, Dafna 2008. Gender representations in the media. International Encyclopedia of Communication, Vol. V. Blackwell Publishing, Oxford, pp. 1945-1951.

Nussbaum, Martha 2010. Objectification and Internet misogyny. In: S. Levmore \& M. Nussbaum (eds.) The offencive Internet: Privacy, speech and reputation. Cambridge, MA: Harvard University Press.

Oring, Elliott 2003. Engaging humor. Urbana, Chicago: Illinois University Press.

Rappoport, Leon 2005. Punchlines: The case for racial, ethnic and gender humor. London: Praeger.

Raskin, Victor 1985. Semantic mechanisms of humor. Dordrecht: Reidel.

Shifman, Limor \& Lemish, Dafna 2010. Between feminism and fun(ny)mism: Analyzing gender in popular Internet humor. Information, Communication and Society 13(6), pp. 870-891 (preprint version).

Shifman, Limor \& Maapil Varsano, Hamutal 2007. The Clean, the dirty and the ugly: A critical analysis of clean humour websites. First Monday 12(2). http://firstmonday.org/htbin/cgiwrap/bin/ojs/index.php/fm/article/view/1621/1536, last accessed in February 2012.

Strean, Herbert 1993. Jokes: Their purpose and meaning. Northvale: Jason Aronson Inc. Thielemann, Nadine 2011. Displays of "new" gender arrangements in Russian jokes. In: M. Dynel (ed.) The pragmatics of humour across discourse domains. Amsterdam, Philadelphia: John Benjamins, pp. 147-172.

Zoonen, van Liesbet 1994. Feminist media studies. Thousand Oaks, CA: Sage.

Winick, Charles 1976. The social contexts of humor. Journal of communication 26, pp. 124-128.

\section{Humour sources}

Delfi. Delfi naljaleht. http: / / vimka.delfi.ee / ?filter=anecdote, last accessed on 20 February 2012.

Eesti Päevaleht. Eino Baskini anekdoodid eesti kaasaegsete anekdootide andmebaasis. [Eino Baskin's jokes. Database of Estonian contemporary jokes.] http://www.folklore. ee/ liisi/o2/, last accessed on 2 January 2012.

Ivar Kallion 2011. Nõuka-aja anekdoodid. [Soviet jokes.] Tallinn: Tammerraamat.

Jüri Viikberg 1997. Naeruga eilsest. [Merrily about yesterday.] Tallinn: Eesti Keele Sihtasutus.

Kuldar Metsa naljakogu. Eesti kaasaegsete anekdootide andmebaas. [Database of Estonian contemporary jokes.] http://www.folklore.ee/ liisi/o2/, last accessed on 2 January 2012.

Meie naljaraamat. Eesti kaasaegsete anekdootide andmebaas. [Database of Estonian contemporary jokes.] http://www.folklore.ee/ liisi/o2/, last accessed on 2 January 2012.

Sõnumileht Online. Eesti kaasaegsete anekdootide andmebaas. [Database of Estonian contemporary jokes.] http://www.folklore.ee/ liisi/o2/, last accessed on 2 January 2012. 


\title{
APPENDIX 1. Categorisation
}

\section{Location:}

home

Interaction:

\author{
bathroom \\ bedroom \\ kitchen \\ living room
}

outside

\author{
public space anonymous \\ city space \\ nature space \\ public transport \\ public space personal \\ workplace \\ church \\ court/police/jail \\ doctor's office \\ entertainment venue \\ restaurant \\ school \\ shop
}

\section{family}

animal

children/grandchildren

husband

mother/father

non-related

relatives through marriage

Sexual content:

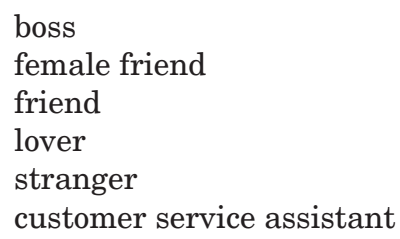

no

yes

Role of the woman:

\section{General:}

side character

subject

target of the joke

inside home

not at home

relative

not relative 